
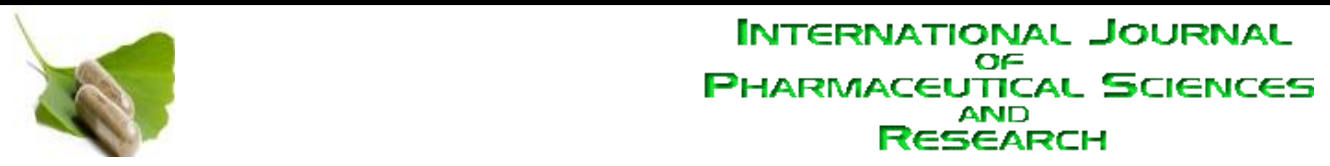

Received on 19 March, 2011; received in revised form 18 May, 2011; accepted 30 May, 2011

\title{
EVALUATION OF ANTICONVULSANT ACTIVITY OF SEMECARPUS ANACARDIUM (LINN.) NUT EXTRACT
}

\author{
P. Basavaraj*1, B. Shivakumar ${ }^{2}$, H. Shivakumar ${ }^{3}$ Manjunath ${ }^{1}$ Nanjappaiah H M $^{3}$
}

Department of Pharmacology, T.V.M.College of Pharmacy ${ }^{1}$, Bellary, Karnataka, India Department of Pharmaceutical Chemistry ${ }^{2}$ and Pharmacology ${ }^{3}$, B.L.D.E.A's College of Pharmacy, Bijapur, Karnataka, India

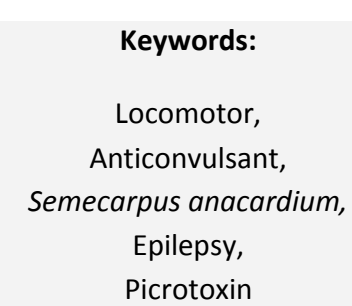

Correspondence to Author:

Basavaraj Pujar

Research scholar, Department of Pharmacology, T.V.M.College of Pharmacy, Bellary, Karnataka, India

\section{ABSTRACT}

The present study was undertaken to evaluate the locomotor effect of chloroform extract of Semecarpus anacardium (Linn.) (CHSA) by using photoactometer. Its anticonvulsant property was tested against maximal electroshock (MES)-induced convulsion (MESIC), pentalenetetrazol (PTZ)induced convulsion (PTZIC), strychnine-induced convulsion (SIC), picrotoxininduced convulsion (PIC), isoniazid (INH)-induced convulsion (IIC) and 4amino pyridine (4-AP)-induced convulsion (4-APIC) in mice. The gammaamino butyric acid (GABA) level was estimated by spectroscopic method. Significant reduction in locomotor scores were recorded with a diazepam (5 $\mathrm{mg} / \mathrm{kg}$ ) but not with CHSA $(100,200 \& 400 \mathrm{mg} / \mathrm{kg}$ ). In MESIC a phenytoin (25 $\mathrm{mg} / \mathrm{kg}$ ) was possessed anticonvulsant activity by decreased duration of tonic extension phase of the animals but not with CHSA. In PTZIC, SIC PIC, IIC and 4-APMIC models, a diazepam exhibited anticonvulsant effect, the CHSA was ineffective among all those paradigms. Increased GABA level in the mice serum was observed with a gabapentin $(20 \mathrm{mg} / \mathrm{kg})$ treated group, in CHSA such effect was not observed. Hence it concluded that Semecarpus anacardium (Linn.) not possesses sedative and anticonvulsant properties.
INTRODUCTION: Epilepsy is a neurological disorder that affects a wide range of people throughout the world. It is a disorder of brain characterize by unpredictable and periodic occurrence of a transient alteration of behaviour due to the disordered, synchronous and rhythmic firing of populations of brain neurons ${ }^{1}$. It has been observed that the presently available antiepileptic drugs are unable to control seizures effectively in as many as $25 \%$ of the patients ${ }^{2,3}$. The conventional antiepileptic agents like phenytoin, carbamazeipine and sodium valporate carry with them several serious side effects notably neurotoxicity ${ }^{4}$. As majority of antiepileptic drugs are consumed life long, concomitant administration of other drugs predisposes to the risk of drug interaction.
However, newer antiepileptics like gabapentin, vigabatrin, lamotrigine etc are used supplemental to the conventional agents ${ }^{1}$.

Thus, it is necessary to investigate for an antiepileptic agent that is highly efficacious as well as safe in items of drug related toxicity. The aim of treating an epileptic is not only to abolish the occurrence of seizures but also to lead a self sustained life.

In the present study, we selected a plant namely Semecarpus anacardium (Linn.) belonging to the family of Anacardiaceae. It is distributed in the sub-Himalayan tract from the Bias eastwards, ascending in the outer hills up to $3,500 \mathrm{ft}$., Assam, Khasia hills, Chittagong, 
Central India and the Western Peninsula. The fruit is acrid hot, sweetish; digestible, aphrodisiac, antihelmentic; stays looseness of bowels; removes "vata", "kapha", ascites, skin diseases, piles, dysentery, tumours, fevers, loss of appetite, urinary discharges; heals ulcers; strengthens the teeth; useful in insanity, asthma. The oil is tonic, makes hair black; good for leucoderma, coryza, epilepsy and other nervous diseases; lessens inflammation; useful in paralysis and superficial pain ${ }^{5}$.

Earlier the plant has been studied for its analgesic and anti-inflammatory ${ }^{6}$, anti-arthritic ${ }^{7}$, antimicrobial ${ }^{8}$, antibacterial ${ }^{9}$, antihelmentic ${ }^{10}$, antimutagenic ${ }^{11}$, antidiabetic ${ }^{12}$, antitumor ${ }^{13}$, antioxidant ${ }^{14}$, fungistatic ${ }^{15}$, hepatocellular carcinoma ${ }^{16-18}$, hypocholesterolemic 19, hypolipidemic 20, immunomodulatory ${ }^{21}$, and mammary carcinoma ${ }^{22}$ activities. Considering the varied important activities reported in traditional system of medicine with this plant, it was planned to study the effects of nut extract of Semecarpus anacardium (Linn.) on CNS mainly for its locomotor and anticonvulsant activity.

\section{MATERIALS AND METHODS:}

Drugs and Chemicals: Phenytoin, Gabapentin, (Sun Pharmaceutical Industries), Diazepam (Ranbaxy Laboratories Ltd.), PTZ (Sigma Aldrich Pvt. Ltd.,), INH (sd. Fine chemicals Pvt.) Strychnine, Picrotoxin, 4Amino pyridine (HiMedia Laboratories).

Animals: Albino mice weighing between $18-22 \mathrm{~g}$ of either sex were used for in this study. All the animals were procured from Shri Venkateswara Enterprises, Bangalore for experimental purpose. After procuring, all the animals were acclimatized for 7 days and housed in groups of 06 under standard husbandry condition ${ }^{23}$ like room temperature $26 \pm 2^{\circ} \mathrm{C}$, relative humidity $45-55 \%$ and light/ dark cycle of $12 \mathrm{~h}$. All the animals were fed with synthetic standard diet (Pranava Agro Industries Ltd., Bangalore.) and water was provided ad libitum under strict hygienic conditions. After obtaining permission from Institutional Animal Ethical Committee (IAEC) of T.V.M. College of Pharmacy, Bellary (Karnataka), animal studies were performed as per rules and regulations in accordance to guideline of CPCSEA with R. No. 462/01/CPCSEA, 2001.

Plant Material: The nuts of Semecarpus anacardium (Linn.) was collected from local market of Bellary (Karnataka State) and authenticated and identified by a Botanist Dr. Govind Raju of A.S.M. College Bellary. The nuts were dried in shadow and slices of nuts were subjected to size reduction by using a mixer to coarse powder.

Preparation of Chloroform Extract ${ }^{24,25}$ : The air dried nuts were extracted successively with the following solvents of their increasing polarity in a soxhlet extractor.
1) Pet. Ether (60-80\%),
2) Chloroform,
3) Alcohol

After alcoholic extraction macerated the mark with chloroform water for $24 \mathrm{~h}$ to obtained the aqueous extract. Concentrate the each extract solvent by using flash evaporator to dryness on the water bath in low heat. Weighed the residue obtained with each solvent and determine its \% in terms of air dried weight to the nut material $(\% \mathrm{w} / \mathrm{w})$ to obtained successive solvent extractive values. On the basis of $\%$ yield highest percentage of the extract was selected for the study.

Preliminary Phytochemical Screening ${ }^{24}{ }^{25}$ : The preliminary phytochemical investigations were carried out with CHSA for qualitative identification of phytochemical constituents. Phytochemical tests were carried out by standard methods. All the chemicals and reagents used were of analytical grade.

\section{Pharmacological Activities:}

Determination of Acute Toxicity $\left(\mathbf{L D}_{50}\right)^{26}$ : The acute toxicity of CHSA was determined by using albino mice of either sex (18-22 g). The animals were fasted $3 \mathrm{~h}$ prior to the experiment, Acute Toxic Class method (OECD guideline No. 423) of CPCSEA was adopted for toxicity studies. Animals were administered with single dose of extract and observed for its mortality during 48 h study period (short term toxicity). Based on shortterm toxicity profile of extract the dose for the next animal was determined as per as OECD guideline No. 423. 
Locomotor activity ${ }^{27,}{ }^{28}$ : Albino mice (18-22 g) of either sex were divided into 05 groups of 06 mice in each was fasted overnight prior to the test but water was supplied ad libitum. Group I was maintained as normal control which was given with $3 \%$ PEG $(10 \mathrm{ml} / \mathrm{kg}$ p.o.) only once daily for 7 days, group II received diazepam (5 mg/kg, i.p.) before test. Groups III, IV and $\checkmark$ were treated with different doses of CHSA $(100,200$ and $400 \mathrm{mg} / \mathrm{kg}$, p.o.) respectively once daily for 7 days.

The experiment was conducted in a sound attenuated room. A drug with increased or decreased CNS activity will also produce increase or decrease in locomotor activity in the animals. Photoactometer (INCO, Ambala, India) is designed on this principle consists of a cage with $30 \mathrm{~cm}$. long and $30 \mathrm{~cm}$. deep with a wire mesh at the bottom. Six lights and 6 photocells were placed in the outer periphery of the bottom in such a way that a single mouse can block only one beam. Technically its principle is that a photocell is activated when animals crossing the beam of light "cut off" the rays of light falling on photocells. The photocells are connected to an electronic automatic counting device, which counts the number of "cut offs". On the $7^{\text {th }}$ day, after treatment of last dose each mouse was placed individually in the actophotometer for $10 \mathrm{~min}$. Number of "cut offs" i.e., locomotor scores was recorded at the prefixed time interval i.e., Initial, $0.5 \mathrm{~h}, 1 \mathrm{~h}$ and $2 \mathrm{~h}$.

\section{Anticonvulsant activity:}

MES induced convulsion ${ }^{29-30}$ : Five groups of mice each comprising 06 animals, weighing between 18-22 g were used. Group I was maintained as normal control which was given with $3 \%$ PEG only $(10 \mathrm{ml} / \mathrm{kg}$ p.o.) only once daily for 7 days. Group II was injected with phenytoin $\left(25 \mathrm{mg} / \mathrm{kg}\right.$, i.p.) alone on $1^{\text {st }}$ day and after 30 min a $60 \mathrm{~mA}$ current was delivered transauricularly for $0.2 \mathrm{sec}$ on mice via small alligator clips attached to cornea by using ECM and different phases of convulsions were recorded. Groups III, IV and V were treated with different doses of CHSA (100, 200 and 400 $\mathrm{mg} / \mathrm{kg}$ p.o.) respectively once daily for 7 days. On $7^{\text {th }}$ day 60 min after administration of $3 \%$ PEG and extract into the respective groups, a $60 \mathrm{~mA}$ current was delivered transauricularly for $0.2 \mathrm{sec}$ in mice via small alligator clips attached to cornea by using ECM and different phases of convulsion were recorded.

PTZ induced convulsion in mice ${ }^{31,32}$ : Albino mice (18$22 \mathrm{~g}$ ) of either sex were divided into 05 groups of 06 mice in each was fasted overnight prior to the test but water was supplied ad libitum. Group I was maintained as control which was given with $3 \%$ PEG (10 ml/kg p.o.) once daily for 7 days. Group II was administered with diazepam ( $5 \mathrm{mg} / \mathrm{kg}$ i.p.) alone on $1^{\text {st }}$ day only after 30 min treatment anticonvulsant activity was recorded.

Groups III, IV and V were treated with different doses of CHSA (100, 200 and $400 \mathrm{mg} / \mathrm{kg}$ p.o.) respectively once daily for 7 days. On $7^{\text {th }}$ day $60 \mathrm{~min}$ after $3 \%$ PEG and extract administration into the respective groups, PTZ (80 mg/kg i.p.) was administered. The following parameters were recorded during test session of initial, $30 \mathrm{~min}$ and up to $24 \mathrm{~h}$. Latency (onset of clonus), onset of tonic convulsion, status of animal after $30 \mathrm{~min}$, status of animal after $24 \mathrm{~h}$ and percentage protection.

Strychnine induced convulsions in mice ${ }^{33-35}$ : Albino mice (18-22 g) of either sex were divided into 05 groups of 06 mice in each was fasted overnight prior to the test but water was supplied ad libitum. Group I was maintained as control which was given with 3\% PEG (10 ml/kg p.o.) once daily for 7 days. Group II was administered with diazepam (5 mg/kg i.p.) alone on $1^{\text {st }}$ day only; $30 \mathrm{~min}$ after administration (diazepam) strychnine was administered.

Groups III, IV and V were treated with different doses of CHSA (100, 200 and $400 \mathrm{mg} / \mathrm{kg}$ p.o.) respectively once daily for 7 days. On $7^{\text {th }}$ day 60 min after $3 \%$ PEG and extract administration into the respective groups, strychnine was administered. The following parameters were recorded during test session of initial, $30 \mathrm{~min}$ and up to $24 \mathrm{~h}$. Latency (onset of clonus), onset of tonic convulsion, status of animal after $30 \mathrm{~min}$, status of animal after $24 \mathrm{~h}$ and percentage protection.

Picrotoxin induced convulsion ${ }^{33,36}$ : Albino mice (18-22 g) of either sex were divided into 05 groups of 06 mice in each was fasted overnight prior to the test but water was supplied ad libitum. Group I was maintained as 
control which was given with $3 \%$ PEG (10 ml/kg p.o.) once daily for 7 days. Group II was administered with diazepam (5 mg/kg i.p.) alone on $1^{\text {st }}$ day only $30 \mathrm{~min}$ after administration (diazepam) picrotoxin was administered. Groups III, IV and V were treated with different doses of CHSA (100, 200 and $400 \mathrm{mg} / \mathrm{kg}$ p.o.) respectively once daily for 7 days. On $7^{\text {th }}$ day $60 \mathrm{~min}$ after 3\% PEG and extract administration into the respective groups, picrotoxin was administered. The following parameters were recorded during test session of initial, $30 \mathrm{~min}$ and up to $24 \mathrm{~h}$. Latency (onset of clonus), onset of tonic convulsion, status of animal after $30 \mathrm{~min}$, status of animal after $24 \mathrm{~h}$ and percentage protection.

INH induced convulsion ${ }^{33,37}$ : Albino mice (18-22 g) of either sex were divided into 05 groups of 06 mice in each was fasted overnight prior to the test but water was supplied ad libitum. Group I was maintained as control which was given with $3 \%$ PEG (10 ml/kg p.o.) once daily for 7 days. Group II was administered with diazepam (5 mg/kg i.p.) alone on $1^{\text {st }}$ day only; $30 \mathrm{~min}$ after administration (diazepam) INH was administered. Groups III, IV and V were treated with different doses of CHSA (100, 200 and $400 \mathrm{mg} / \mathrm{kg}$ p.o.) respectively once daily for 7 days. On $7^{\text {th }}$ day 60 min after $3 \%$ PEG and extract administration into the respective groups, INH was administered. The following parameters were recorded during test session of initial, $30 \mathrm{~min}$ and up to 24 h. Latency (onset of clonus), onset of tonic convulsion, status of animal after $30 \mathrm{~min}$, status of animal after $24 \mathrm{~h}$ and percentage protection.

4-AP induced convulsions ${ }^{33,38,39}$ : Animals in group I served as control were treated with $3 \%$ PEG $(10 \mathrm{ml} / \mathrm{kg}$ p.o.) once daily for 7 days. Group II served as standard received diazepam (5 mg/kg i.p.) alone on $1^{\text {st }}$ day only; 30 min after administration (diazepam) 4-AP was administered. Groups III, IV and V received CHSA (100, 200 and $400 \mathrm{mg} / \mathrm{kg}$ p.o.) once daily for 7 days. On $7^{\text {th }}$ day 60 min after administration of $3 \%$ PEG into the respective groups and extract $4-A P(13.3 \mathrm{mg} / \mathrm{kg}$ i.p) was administered. The following parameters were recorded during test session of initial, $30 \mathrm{~min}$ and up to 24 h. Latency (onset of clonus), onset of tonic convulsion, status of animal after $30 \mathrm{~min}$, status of animal after $24 \mathrm{~h}$ and percentage protection.
Estimation of GABA by spectrophotometer method ${ }^{40,}$

${ }^{41}$ : Animals of group I was maintained as control were treated with $3 \%$ PEG $(10 \mathrm{ml} / \mathrm{kg}$ p.o.) once daily for 7 days. Group II was administered with gabapentin (20 $\mathrm{mg} / \mathrm{kg}$ i.p.) alone on $1^{\text {st }}$ day only $30 \mathrm{~min}$ after administration (gabapentin) blood sample was collected through caudal vein. Groups III, IV and V were treated extract at different dose level of 100, 200 and $400 \mathrm{mg} / \mathrm{kg}$ p.o. respectively once daily for 7 days. On $7^{\text {th }}$ day 60 min after administration of vehicle and extract, blood sample was collected through caudal vein of the each animal. The serum was separated and transferred into plastic tubes and serum samples were stored at $-20^{\circ} \mathrm{C}$ until analysis. All the glass and polypropylene equipments used for trace elements analysis were soaked in $10 \%(\mathrm{~V} / \mathrm{V})$ nitric acid for $12 \mathrm{~h}$ and then rinsed with double distilled deionised water.

The serum sample $(0.1 \mathrm{ml})$ was added to $1.5 \mathrm{ml}$ of absolute alcohol and centrifuged at $3000 \mathrm{~g}$ for $15 \mathrm{~min}$. The upper layer was aspirated and $0.3 \mathrm{ml}$ was put on Whatman's filter paper which was dipped in phenol solution for $24 \mathrm{~h}$ and subsequently dried in air. There after ninhydrin salt solution was sprayed on chromatographic paper and heated at $65^{\circ} \mathrm{C}$ for $10 \mathrm{~min}$. The spot developed due to chromatographic mobility of GABA was cut and put in $3 \mathrm{ml}$ solution of absolute alcohol for elution. The optical density was taken on a spectrophometer at wavelength of $509 \mathrm{~nm}$ and compared with standard GABA solution $(0.1 \mathrm{ug} / \mathrm{ml})$.

Statistical analysis: The results obtained with various experiments were subjected to statistical analysis by using One-way ANOVA followed by Dunnett test to assess the significance difference if any among the groups and $\mathrm{P}<0.05$ was considered as significant.

\section{RESULTS:}

\section{Pharmacological investigations:}

Acute toxicity studies: An acute toxicity study of CHSA was determined in mice, as per OECD guidelines No. 423. The extract was administered orally to different groups of mice at different dose levels and extract produced no mortality up to $2000 \mathrm{mg} / \mathrm{kg}$. Hence, $1 / 5^{\text {th }}$, $1 / 10^{\text {th }}$ and $1 / 20^{\text {th }}$ of $L D_{50}$ doses were selected for the present study. 
Effect of extract on locomotor activity in mice: A standard diazepam treated group exhibited a significant sedative effect by decreasing locomotor activity in a test period when compared to control TABLE 1: EFFECT OF CHSA ON LOCOMOTOR ACTIVITY (ACTOPHOTOMETER) IN MICE group. However there is no significant result was observed with CHSA. It indicates the extract not having CNS activity (Table 1).

\begin{tabular}{|c|c|c|c|c|c|c|}
\hline \multirow{3}{*}{ Groups No } & \multirow{3}{*}{ Treatment } & \multirow{3}{*}{ Dose (Per kg) } & \multicolumn{4}{|c|}{ Number of movements (Scores) } \\
\hline & & & Initial & $0.5 \mathrm{~h}$ & $1 \mathrm{~h}$ & $2 \mathrm{~h}$ \\
\hline & & & Mean \pm SEM & Mean \pm SEM & Mean \pm SEM & Mean \pm SEM \\
\hline Group I & Control 3\% PEG & $10 \mathrm{ml} \mathrm{p.o}$ & $287.17 \pm 3.563$ & $288.33 \pm 3.403$ & $287.33 \pm 5.226$ & $289 \pm 4.824$ \\
\hline Group II & Diazepam & 5 mg i.p. & $285.50 \pm 3.704^{* *}$ & $72.16 \pm 3.842^{* *}$ & $62.667 \pm 2.186^{* *}$ & $48.833 \pm 5.89^{* *}$ \\
\hline Group III & CHSA & 100 mg p.o. & $285.50 \pm 8.318^{\mathrm{ns}}$ & $281.83 \pm 5.7^{\mathrm{ns}}$ & $274.50 \pm 10.41^{\mathrm{ns}}$ & $285.17 \pm 5.88^{\mathrm{ns}}$ \\
\hline Group IV & CHSA & 200 mg p.o. & $296.17 \pm 5.288^{\mathrm{ns}}$ & $289.33 \pm 6.652^{\mathrm{ns}}$ & $287.33 \pm 5.22^{\mathrm{ns}}$ & $287.83 \pm 8.09^{\mathrm{ns}}$ \\
\hline Group V & CHSA & 400 mg p.o. & $285.17 \pm 5.121^{\mathrm{ns}}$ & $269.67 \pm 12.57^{\mathrm{ns}}$ & $287.33 \pm 5.22^{\mathrm{ns}}$ & $282.50 \pm 5.78^{\mathrm{ns}}$ \\
\hline
\end{tabular}

$\mathrm{n}=6$. Significance at $\mathrm{P}<0.05^{*},<0.01^{* *}$ and ns-not significant compared with control group

\section{Anticonvulsant activity:}

Effect of extract on MESIC in mice: A standard drug phenytoin exhibited significant anticonvulsant effect by abolishing the tonic extensor phase and offered $100 \%$ animal protection. But the extract was ineffective in this model (Table 2).

TABLE 2: EFFECT OF CHSA ON MES-INDUCED CONVULSIONS IN MICE

\begin{tabular}{|c|c|c|c|c|c|c|}
\hline Groups & Treatment & $\begin{array}{c}\text { Dose } \\
\text { (Per kg) }\end{array}$ & $\begin{array}{l}\text { Latency (Onset of clonus) } \\
\text { Mean } \pm \text { SEM }\end{array}$ & $\begin{array}{l}\text { Duration of tonic flexion } \\
\text { Mean } \pm S E M\end{array}$ & $\begin{array}{l}\text { Duration of the tonic extensor } \\
\text { Mean } \pm \text { SEM }\end{array}$ & $\begin{array}{c}\% \\
\text { Protection }\end{array}$ \\
\hline Group I & $\begin{array}{c}\text { Control (3\% PEG) } \\
+ \text { MES }\end{array}$ & $10 \mathrm{ml} \mathrm{p.o.}$ & $2.0 \pm 0.28$ & $3 \pm 0.258$ & $12.50 \pm 0.61$ & 16 \\
\hline Group II & Phenytoin + MES & $25 \mathrm{mg}$ i.p. & $4.16 \pm 0.30^{* *}$ & $\mathrm{NIL}^{* *}$ & $\mathrm{NIL}^{* *}$ & 100 \\
\hline Group III & $\mathrm{CHSA}+\mathrm{MES}$ & 100 mg p.o. & $2 \pm 0.25^{\mathrm{ns}}$ & $3.16 \pm 0.40^{\mathrm{ns}}$ & $12.167 \pm 0.94^{\mathrm{ns}}$ & 33 \\
\hline Group IV & CHSA +MES & 200 mg p.o. & $1.83 \pm 0.40^{\mathrm{ns}}$ & $3.0 \pm 0.44^{\mathrm{ns}}$ & $12.66 \pm 0.42^{\mathrm{ns}}$ & 16 \\
\hline Group V & $\mathrm{CHSA}+\mathrm{MES}$ & 400 mg p.o. & $1.66 \pm 0.33^{\mathrm{ns}}$ & $3.16 \pm 0.30^{\mathrm{ns}}$ & $12.66 \pm 0.61^{\mathrm{ns}}$ & 33 \\
\hline
\end{tabular}

$\mathrm{n}=6$. Significance at $\mathrm{P}<0.05^{*},<0.01^{* * *}$ and ns-not significant compared with control group

Effect of extract on PTZIC in mice: A standard diazepam treated group showed no convulsion after PTZ treatment it protects $100 \%$ of the animal. In all the doses of CHSA there is no significant anticonvulsant activity was observed (Table $\mathbf{3}$ ).

TABLE 3: EFFECT OF CHSA ON PTZ-INDUCED CONVULSIONS IN MICE

\begin{tabular}{|c|c|c|c|c|c|c|c|}
\hline Groups & Treatment & Dose (Per kg) & $\begin{array}{l}\text { Latency (Onset of } \\
\text { convulsions) } \\
\text { (in sec) Mean } \pm \text { SEM }\end{array}$ & $\begin{array}{c}\text { Onset of tonic } \\
\text { convulsion (in sec) } \\
\text { Mean } \pm \text { SEM }\end{array}$ & $\begin{array}{l}\text { Status of animal } \\
\text { (30 min) (No of } \\
\text { animals alive) }\end{array}$ & $\begin{array}{c}\text { Status of animal } \\
\text { ( } 24 \mathrm{~h} \text { ) (No of } \\
\text { animals alive) }\end{array}$ & $\begin{array}{c}\% \\
\text { Protection }\end{array}$ \\
\hline Group I & $\begin{array}{l}\text { Control (3\% } \\
\text { PEG) + PTZ }\end{array}$ & 10 ml p.o.+ 80 mg i.p. & $39.0 \pm 3.416$ & $206.50 \pm 3.91$ & 2 & 2 & 33 \\
\hline Group II & Diazepam + PTZ & 5 mg i.p.+ 80 mg i.p. & $\mathrm{NIL}^{* *}$ & $\mathrm{NIL}^{* *}$ & 6 & 6 & 100 \\
\hline Group III & $\mathrm{CHSA}+\mathrm{PTZ}$ & 100 mg p.o. +80 mg i.p. & $39 \pm 1.69^{\mathrm{ns}}$ & $215.67 \pm 3.21^{\mathrm{ns}}$ & 4 & 3 & 50 \\
\hline Group IV & $\mathrm{CHSA}+\mathrm{PTZ}$ & 200 mg p.o. +80 mg i.p. & $40.33 \pm 3.74^{\mathrm{ns}}$ & $201 \pm 8.56^{\mathrm{ns}}$ & 4 & 2 & 33 \\
\hline Group V & $\mathrm{CHSA}+\mathrm{PTZ}$ & 400 mg p.o. +80 mg i.p. & $36.83 \pm 1.95^{\mathrm{ns}}$ & $206.50 \pm 8.29^{\mathrm{ns}}$ & 5 & 3 & 50 \\
\hline
\end{tabular}

$\mathrm{n}=6$. Significance at $\mathrm{P}<0.05^{*},<0.01^{* *}$ and ns-not significant compared with control group

Effect of extract in SIC on mice: A standard diazepam treated group showed no convulsion after strychinine treatment it protects $100 \%$ of the animal.
But not recorded anticonvulsant with the CHSA (Table 4). 
TABLE 4: EFFECT OF CHSA ON STRYCHININE-INDUCED CONVULSIONS IN MICE

\begin{tabular}{|c|c|c|c|c|c|c|c|}
\hline Groups & Treatment & Dose (Per kg) & $\begin{array}{c}\text { Latency (Onset of } \\
\text { convulsions) } \\
\text { (in sec) Mean } \pm \text { SEM }\end{array}$ & $\begin{array}{c}\text { Onset of tonic } \\
\text { convulsion } \\
\text { (in sec) Mean } \pm \text { SEM }\end{array}$ & $\begin{array}{l}\text { Status of animal } \\
\text { ( } 30 \mathrm{~min} \text { ) (No of } \\
\text { animals alive) }\end{array}$ & $\begin{array}{c}\text { Status of animal } \\
\text { ( } 24 \mathrm{~h} \text { ) (No of } \\
\text { animals alive) }\end{array}$ & $\begin{array}{c}\% \\
\text { Protection }\end{array}$ \\
\hline Group I & $\begin{array}{l}\text { Control (3\%PEG) } \\
+ \text { Strychinine }\end{array}$ & $10 \mathrm{ml} \mathrm{p.o.+} 2 \mathrm{mg}$ i.p. & $129.83 \pm 2.71$ & $331 \pm 4.23$ & 2 & NIL & NIL \\
\hline Group II & $\begin{array}{l}\text { Diazepam + } \\
\text { Strychinine }\end{array}$ & 5 mg i.p. +2 mg i.p. & $\mathrm{NIL}^{* *}$ & $\mathrm{NIL}^{* *}$ & 5 & 4 & 66 \\
\hline Group III & $\begin{array}{c}\text { CHSA + } \\
\text { Strychinine }\end{array}$ & 100 mg p.o.+ 2 mg i.p. & $130.33 \pm 4.22^{\mathrm{ns}}$ & $354.50 \pm 25.36^{\mathrm{ns}}$ & 3 & 2 & 33 \\
\hline Group IV & $\begin{array}{c}\text { CHSA+ } \\
\text { Strychinine }\end{array}$ & 200 mg p.o.+ 2 mg i.p. & $125.67 \pm 1.68^{\mathrm{ns}}$ & $336.83 \pm 17.74^{\mathrm{ns}}$ & 3 & 2 & 33 \\
\hline Group V & $\begin{array}{c}\text { CHSA + } \\
\text { Strychinine }\end{array}$ & 400 mg p.o.+2 mg i.p. & $127 \pm 2.22^{\mathrm{ns}}$ & $331.17 \pm 4.72^{\mathrm{ns}}$ & 5 & 3 & 50 \\
\hline
\end{tabular}

Effect of extract on PIC in mice: A standard drug diazepam exhibited anticonvulsant effect by increased time for onset and tonic convulsion after picrotoxin and offered $100 \%$ protection. In all the doses of CHSA there is no significant anticonvulsant activity was observed (Table 5).

\section{TABLE 5: EFFECT OF CHSA ON PICROTOXIN-INDUCED CONVULSIONS IN MICE}

\begin{tabular}{|c|c|c|c|c|c|c|c|}
\hline Groups & Treatment & Dose (Per kg) & $\begin{array}{c}\text { Latency (Onset of } \\
\text { convulsions) } \\
\text { (in sec) Mean } \pm \text { SEM }\end{array}$ & $\begin{array}{l}\text { Onset of tonic } \\
\text { convulsion } \\
\text { (in sec) } \\
\text { Mean士SEM }\end{array}$ & $\begin{array}{l}\text { Status of animal } \\
\text { ( } 30 \mathrm{~min} \text { ) (No of } \\
\text { animals alive) }\end{array}$ & $\begin{array}{l}\text { Status of animal } \\
\text { ( } 24 \mathrm{~h} \text { ) (No of } \\
\text { animals alive) }\end{array}$ & $\begin{array}{c}\% \\
\text { Protection }\end{array}$ \\
\hline Group I & $\begin{array}{c}\text { Control } \\
\text { (3\% PEG) + } \\
\text { Picrotoxin }\end{array}$ & $10 \mathrm{ml}$ p.o.+ $3.5 \mathrm{mg}$ i.p. & $130 \pm 5.20$ & $268.67 \pm 15.98$ & 4 & 1 & 16 \\
\hline Group II & $\begin{array}{c}\text { Diazepam+ } \\
\text { Picrotoxin }\end{array}$ & 5 mg p.o.+3.5 mg i.p. & $338.67 \pm 37.74^{* *}$ & $618.17 \pm 42.65^{* *}$ & 6 & 6 & 100 \\
\hline Group III & CHSA+ Picrotoxin & 100 mg p.o.+3.5 mg i.p. & $180.83 \pm 14.18^{\mathrm{ns}}$ & $262.67 \pm 13.89^{\mathrm{ns}}$ & 5 & 2 & 33 \\
\hline Group IV & CHSA+ Picrotoxin & 200 mg p.o.+ 3.5 mg i.p. & $138.50 \pm 14.59^{\mathrm{ns}}$ & $281.33 \pm 17.20^{\mathrm{ns}}$ & 4 & 3 & 50 \\
\hline Group V & CHSA+ Picrotoxin & 400 mg p.o. $+3.5 \mathrm{mg}$ i.p & $125.50 \pm 11.20^{\mathrm{ns}}$ & $240.33 \pm 17.202^{\mathrm{ns}}$ & 3 & 3 & 50 \\
\hline
\end{tabular}

$\mathrm{n}=6$.Significance at $\mathrm{P}<0.05^{*},<0.01^{* *}$ and ns-not significant compared with control group

Effect of extract on IIC in mice: No convulsion was the mice. In all the doses of CHSA there is no significant recorded with diazepam and it protect up to $100 \%$ of anticonvulsant activity was observed (Table 6).

TABLE 6: EFFECT OF CHSA ON INH-INDUCED CONVULSIONS IN MICE

\begin{tabular}{|c|c|c|c|c|c|c|c|}
\hline Groups & Treatment & Dose (Per kg) & $\begin{array}{c}\text { Latency (Onset of } \\
\text { convulsions) } \\
\text { (in sec) Mean } \pm \text { SEM }\end{array}$ & $\begin{array}{l}\text { Onset of tonic } \\
\text { convulsion (in } \\
\text { sec) Mean } \pm \text { SEM }\end{array}$ & $\begin{array}{c}\text { Status of animal } \\
\text { ( } 30 \mathrm{~min} \text { ) (No. of } \\
\text { animals alive) }\end{array}$ & $\begin{array}{c}\text { Status of animal } \\
\text { ( } 24 \mathrm{~h}) \text { (No. of } \\
\text { animals alive) }\end{array}$ & $\begin{array}{c}\% \\
\text { Protection }\end{array}$ \\
\hline Group I & $\begin{array}{l}\text { Control }(3 \% \\
\text { PEG) + INH }\end{array}$ & $10 \mathrm{ml}$ p.o.+ 300 mg p.o. & $135.67 \pm 8.29$ & $253 \pm 29.17$ & 5 & 2 & 33 \\
\hline Group II & $\begin{array}{c}\text { Diazepam + } \\
\text { INH }\end{array}$ & 5 mg i.p.+300 mg p.o. & $\mathrm{NIL}^{* *}$ & $\mathrm{NIL}^{* *}$ & 6 & 5 & 100 \\
\hline Group III & $\mathrm{CHSA}+\mathrm{INH}$ & 100 mg p.o.+300 mg p.o. & $142.17 \pm 6.69^{\mathrm{ns}}$ & $272.33 \pm 10.19^{\mathrm{ns}}$ & 5 & 3 & 50 \\
\hline Group IV & $\mathrm{CHSA}+\mathrm{INH}$ & 200 mg p.o. $+300 \mathrm{mg}$ p.o. & $133.83 \pm 3.47^{\mathrm{ns}}$ & $270.00 \pm 5.279^{\mathrm{ns}}$ & 3 & 2 & 33 \\
\hline Group V & $\mathrm{CHSA}+\mathrm{INH}$ & 400 mg p.o.+300 mg p.o. & $135.67 \pm 3.084^{\mathrm{ns}}$ & $293.83 \pm 25.33^{\mathrm{ns}}$ & 3 & 3 & 50 \\
\hline
\end{tabular}

$\mathrm{n}=6$.Significance at $\mathrm{P}<0.05^{*},<0.01^{* *}$ and ns-not significant compared with control group

Effect of extract on 4-APIC in mice: A standard drug But ineffective with all the doses of CHSA were diazepam treated groups not suffered from convulsion observed (Table 7).

and protects up to $100 \%$ of the animal. 
TABLE 7: EFFECT OF CHSA ON 4-AMINOPYRIDINE-INDUCED CONVULSIONS IN MICE

\begin{tabular}{|c|c|c|c|c|c|c|c|}
\hline Groups & Treatment & Dose (Per kg) & $\begin{array}{l}\text { Latency (Onset of } \\
\text { convulsions) (in } \\
\text { sec) Mean } \pm \text { SEM }\end{array}$ & $\begin{array}{l}\text { Onset of tonic } \\
\text { convulsion (in } \\
\text { sec) Mean士SEM }\end{array}$ & $\begin{array}{l}\text { Status of animal } \\
\text { ( } 30 \mathrm{~min} \text { ) (No of } \\
\text { animals alive) }\end{array}$ & $\begin{array}{l}\text { Status of animal } \\
\text { (24 h) (No of } \\
\text { animals alive) }\end{array}$ & $\begin{array}{c}\% \\
\text { Protectio } \\
\mathbf{n}\end{array}$ \\
\hline Group I & $\begin{array}{c}\text { Control } \\
(3 \% \text { PEG) }+4-A P\end{array}$ & 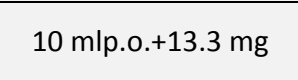 & $153.33 \pm 13.64$ & $211.50 \pm 14.21$ & 4 & 2 & 33 \\
\hline Group II & Diazepam +4- AP & $5 \mathrm{mg}$ i.p. $+13.3 \mathrm{mg}$ & $484.50 \pm 21.902^{* *}$ & $\mathrm{NIL}^{* *}$ & 6 & 6 & 100 \\
\hline Group III & $\mathrm{CHSA}+4-\mathrm{AP}$ & $100 \mathrm{mg}$ p.o. +13.3 mg & $166.83 \pm 12.49^{\mathrm{ns}}$ & $232.67 \pm 22.54^{\mathrm{ns}}$ & 4 & 3 & 50 \\
\hline Group IV & $\mathrm{CHSA}+4-\mathrm{AP}$ & 200 mg p.o.+13.3 mg & $158.17 \pm 5.5^{\mathrm{ns}}$ & $214.00 \pm 5.68^{\mathrm{ns}}$ & 5 & 2 & 33 \\
\hline Group V & $\mathrm{CHSA}+4-\mathrm{AP}$ & 400 mg p.o.+13.3 mg & $189.50 \pm 7.24^{\mathrm{ns}}$ & $230.50 \pm 8.73^{\mathrm{ns}}$ & 5 & 3 & 50 \\
\hline
\end{tabular}

$\mathrm{n}=6$. Significance at $\mathrm{P}<0.05^{*},<0.01^{* *}$ and ns-not significant compared with control group

Effect of extract on mice serum GABA levels: $A$ standard gabapentin significantly increased GABA levels in the serum of mice. However no increased

TABLE 8: EFFECT OF ALEPT ON SERUM GABA LEVELS OF MICE

\begin{tabular}{ccccc}
\hline Groups & Treatment & Dose (Per kg) & $\begin{array}{c}\text { Optical density (509 nm) } \\
\text { Mean } \pm \text { SEM }\end{array}$ & $\begin{array}{c}\text { GABA (pmol/ml) Levels } \\
\text { Mean } \pm \text { SEM }\end{array}$ \\
\hline Group I & (D.water) & $10 \mathrm{ml} \mathrm{p.o.}$ & $0.021 \pm 0.0006$ & 152.17 \\
Group II & Gabapentin & $20 \mathrm{mg} \mathrm{i.p.}$ & $0.084 \pm 0.001$ & $466.66^{* *}$ \\
Group III & ALEPT & $50 \mathrm{mg} \mathrm{p.o.}$ & $0.0321 \pm 0.001$ & $331.88^{*}$ \\
Group IV & ALEPT & $100 \mathrm{mg} \mathrm{p.o.}$ & $0.058 \pm 0.002$ & $420.28^{* *}$ \\
Group V & ALEPT & $200 \mathrm{mg} \mathrm{p.o.}$ & $0.0435 \pm 0.020$ & $311.59^{* *}$ \\
Group VI & Standard GABA & $0.1 \mathrm{ug} / \mathrm{ml}$ & $0.138 \pm 0.005$ & $1000^{* *}$ \\
\hline
\end{tabular}

$\mathrm{n}=6$. Significance at $\mathrm{P}<0.05^{*},<0.01^{* *}$ and ns-not significant compared with control group

GABA levels in the serum of mice were recorded with CHSA. (Table No 8)
DISCUSSION: Currently available anticonvulsant drugs are able to efficiently control epileptic seizures in about $50 \%$ of the patients, another $25 \%$ may show improvement where as the remainder does not benefit significantly. Furthermore, undesirable side effects from the drugs used clinically often render treatment difficult so that a demand for new types of anticonvulsants exists. One of the approaches to search for new antiepileptic drugs is the investigation of naturally occurring compounds, which may belong to new structural classes ${ }^{2}$.

In most common forms of epileptic seizures, effective drugs appear to work either by promoting the inactivated state of voltage activated $\mathrm{Na}^{+}$channels or enhance GABA mediated synaptic inhibition ${ }^{1}$.

Locomotor activity is considered as an index of alertness and decrease in it is considered in it is indicative of sedative activity ${ }^{42}$. The locomotor activity was studied on CHSA there was no difference with control in decreased the frequency and the amplitude of movements recorded. The reduction of the locomotor activity could be attributed to the sedative effect of the drugs that might be due to increase in concentration of the GABA in GABAergic system.

MES is also one of the commonly used models for preliminary testing of anticonvulsant drugs that produces generalized tonic-clonic seizures i.e. hind limb tonic extensor, tonic flexion and clonic convulsion.

It has often been stated that antiepileptic drugs that block MES induced tonic extension act by blocking seizure spread, moreover MES induced tonic extension can be prevented either by drugs that inhibit voltage dependant $\mathrm{Na}^{+}$channels (phenytoin, valproate) ${ }^{43,44}$ or by drugs that block glutaminergic excitation mediated by the $\mathrm{N}$-methyl- D-aspartate (NMDA) receptor (felbamate) ${ }^{45,46}$.

The phenytoin treated group animals showed anticonvulsant activity against MESIC. The extract treated groups ineffective against MESIC it indicate it might be not interfered with $\mathrm{Na}^{+}$channels or MNDA receptor. 
The PTZ is produced petitmal type of epilepsy. The mechanism by which PTZ is believed to exert its action is by acting as an antagonist at the $\mathrm{GABA}_{\mathrm{A}}$ receptor complex. Several biochemical hypotheses have been advanced involving the inhibitory GABAergic system and the system of the excitatory amino acid glutamate and aspartate ${ }^{47}$. The diazepam showed anticonvulsant activity as a result of increased time taken for onset of convulsion and tonic convulsion induced by PTZ. The anticonvulsant effect of extract not showed against PTZIC it might be not acts as a $\mathrm{GABA}_{A}$ agonist.

In the strychnine-induced seizure model, it is known that strychnine a potent spinal cord convulsant, blocks glycine receptor selectively to induce excitatory response in the $\mathrm{CNS}^{48}$. The CHSA not showed any significant inhibition against SIC, it might be not interfere with glycine transmission. The suppression of seizure by diazepam was indirectly enhancing glycine inhibitory mechanisms ${ }^{49}$.

Picrotoxin is a noncompetitive antagonist at $\mathrm{GABA}_{\mathrm{A}}$ receptors and it blocks the GABA-activated chloride ionophore ${ }^{33}$. However the diazepam was significantly protected animals in PIC, but CHSA was ineffective in this model it shows that the extract ineffective in modification of $\mathrm{GABA}_{A}$ receptor mediated chloride channel.

INH is used widely for the treatment and chemoprophylaxis of tuberculosis, but can have serious effects on the CNS causing seizures and comas 49. The INH is thought to be inhibition of GABA synthesis in the CNS. So diazepam treated group was showed up to $83 \%$ of protection of the animals. But the CHSA not showed significant protection of the animal it was ineffective. The extract might be not having either by stimulation of L-glutamate or prevention of GABA degradation by GABA transaminase.

4-AP is a $\mathrm{K}^{+}$channel blocker and $\mathrm{Ca}^{2+}$ channel stimulator, both voltages dependent gated ${ }^{50,51}$ which shows convulsant action when administered systemically to a variety of species. Furthermore, the convulsant effects of 4-AP is due to the release of excitatory neurotransmitters ${ }^{52}$, where the glutamate is release results in over activation of excitatory amino- acid receptors, mainly the NMDA-type. Indeed, an enhancement in the glutamatergic neurotransmission has been linked to the 4-AP convulsant action ${ }^{53}$, since the administration of NMDA receptor antagonists protected against 4-AP induced seizures ${ }^{54}$. The CHSA not exhibited anticonvulsant activity against 4-APIC it might be not interfere with glutamate signal pathway.

Significantly increased GABA concentration in the serum of the animals was observed with gabapentin 55 treated groups. However there is no difference GABA concentration in serum of animals were observed with CHSA as compared to control group of animals it indicates the extract not enhanced synthesis of GABA in GABAergic neurons.

In conclusion, our result showed that CHSA not possesses anticonvulsant activity probably due to the active constituents present in the extract either inability to modulation of GABAergic system or reduction of neuronal excitability mainly through the voltage-dependent $\mathrm{Na}^{+}$channels.

ACKNOWLEDGEMENT: The authors are grateful to the Management and Principal, T.V.M. College of Pharmacy, Bellary, Karnataka, India, for providing the facilities to carry out the research work

\section{REFERENCES:}

1. Goodman and Gilman's, the pharmacological basis of therapeutics. In: James O. McNamara, editors, Pharmacotherapy of the epilepsies $11^{\text {th }}$ ed. New York: McGraw-Hill publishers; 2001. p. 501-525.

2. Duraisami R, Srinivasan D, Ramaswamy S, Anticonvulsant activity of bioflavonoid gossypin. Bangaladesh J Pharmacol 2009; 4: 5154.

3. Mattson RH, Drug treatment of partial epilepsy, Adv Neurol, 57(1992) 643-650.

4. Gupta YK, Malhotra J, Adenosinergic system as an endogenous anticonvulsant mechanism. J Physilol and Pharmacol 1997; 41: 329-343.

5. Kirtikar K R and Basu B D, Indian medicinal plants, Vol-I, Dehra Dun: Bishen Singh Mahendra Pal Singh publishers; 1998. 666-671.

6. Jabbar S, Khan MTH, Choudhri MSK, Chowdhary NMH and Gafur MA: Analgesic and anti-inflammatory activity of activity of Semecarpus anacardium Linn. Hamdard Medicus 1998; 41 (4): 7380.

7. Vijayalakshmi T, Muthulakshmi V and Sachdanandam P: Effect of the milk extract of Semecarpus anacardium nut on adjuvant arthritis a dose-dependent study in Wistar albino rats. Gen Pharmacol 1996; 27(7): 1223-1226.

8. Nair A and Bhide SV, Antimicrobial properties of different parts of Semecarpus anacardium. Indian drugs 1996; 33: 323-328. 
9. Patwardhan BK, Francis RP, Kapre S V, Sharma K D. Antibacterial activity of Semecarpus anacardium extracts, Bulletin of the Haffkin Institute 1982; 10(2): 27-30.

10. Sharma PV, Chaturvedi C. In-vitro antihelmentic effects of Semecarpus anacardium Linn. J Med Sci 1964; 5(1): 58-68.

11. Kothari AB, Lahiri M, Ghaisas SD, Bhide SV. In-vitro studies on antimutagenecity of water, alcoholic and oil extract of Semecarpus anacardium, Ind J Pharmacol 1997; 29: 301-305.

12. Arul B, Kothai R, Christina AJ. Hypoglycemic and antihyperglycemic effect of Semecarpus anacardium Linn in normal and streptozotocin-induced diabetic rats. Exp Clin Pharmacol 2004; 26(10): 759-62.

13. Indap MA, Ambaye RY, Gokhale SV. Anti-tumour and pharmacological effect of the oil from Semecarpus anacardium Linn. Ind J Physiol Pharmacol 1983; 27: 2.

14. Premalatha B, Sachdanandam P. Semecarpus anacardium L. nut extract administration induces the in vivo antioxidant defence system in aflatoxin B1 mediated hepatocellular carcinoma. J Ethnopharmacol 1999; 66(2): 131-9.

15. Sharma K, Shukla SD, Mehta $P$, Bhatnagar M. Fungistatic activity of nut extracts of Semecarpus anacardium Linn. Ind J Exp Biol 2002; 40: 314-318.

16. Premalatha B, Sachdanandam P. Effect of Semecarpus anacardium nut extracts against aflatoxin B1-induced hepatocellular carcinoma. Fitoterapia 1999; 70: 484- 492.

17. Premalatha B, Sachdanandam P. Semecarpus anacardium L. nut extract administration induces the in vivo antioxidant defence system in aflatoxin B1 mediated hepatocellular carcinoma. J Ethnopharmacol 1999; 66(2): 131-9.

18. Premalatha B, Muthulakshmi V, Sachdanandam P. Anticancer potency of the milk extract of Semecarpus anacardium Linn. nuts against aflatoxin $B_{1}$ mediated hepatocellular carcinoma bearing Wistar rats with reference to tumour marker enzymes. Phytother Res 1999; 13(3): 183-7.

19. Sharma A, Mathur R, Dixit V P. Hypocholesterolemic activity of nut shell extracts of Semecarpus anacardium (Bhilawa) in cholesterol fed rabbits, Indian J. Exp. Biol 1995; 33: 444-448.

20. Tripathi YB, Pandey RS. Semecarpus anacardium L. nuts inhibit lipopolysaccharide induced NO production in rat macrophages along with its hypolipidemic property. Ind J Exp Biol 2004; 42: 432-436.

21. Vanu Ram Kumar Ramprasath, Palavivelu Shanthi, Panchanatham Sachdanandam. Immunomodulatory and Anti-inflammatory effects of Semecarpus anacardium Linn. nut milk extract in experimental inflammatory conditions. Biol Pharma Bull 2006; 29 (4): 693-700.

22. Arathi G, Sachdanandam P. Therapeutic effect of Semecarpus anacardium Linn. nut milk extract on carbohydrate metabolizing and mitochondrial TCA cycle and respiratory chain enzymes in mammary carcinoma in rats. J Pharm Pharmacol. 2003; 55 (9): 1283-90.

23. Buger GT and Miller CL Animal care and facilities, in principles and methods of toxicology. Wallace Hayes A, Raven Press Ltd. New York, Second Edition 1989.

24. Khandelwal KR: Practical Pharmacognosy. Nirali Prakashan Pune, Twentieth Edition 2010.

25. Kokate CK: Practical Pharmacognosy. Vallabh Prakashan New Delhi, Fourth Edition 1994.

26. OECD 2001-guidelines on acute oral toxicity, Environmental health and safety monograph series on testing and adjustment No.423.

27. Goyal RK: Practicals in Pharmacology. Shah Prakashan Ahmedabad. Eight Edition 2008.
28. Mohd Abid HJ, Hrishikeshavan and Mohammed Asad: Pharmacological evaluation of Pachyrrhizus erosus (L) seeds for central nervous system depressant activity. Indian J Physiol Pharmacol 2006; 50: 143-151.

29. Misra AK, Dandiya PC and Kulkarni SK: Anticonvulsant activity of some trimethoxybenzylidene-2-thiohydantion derivatives. Ind J Pharmacol 1973; 5: 449-450.

30. Shirish D, Ambawade, Veena S and Kasture SB: Anticonvulsant activity of roots and rhizomes of Glycyrrhiza Glabra. Ind J Pharmacol 2002; 34: 251-255.

31. Khosala P and Pandhi P: Anticonvulsant effect of nimodipine alone and in combination with diazepam on PTZ induced status epilepticus. Ind J Pharmacol 2001; 33: 208-211.

32. Bhattacharya SK and Sanyal AK: Inhibition of PentalenetetrazolInduced convulsions in rats by prostaglandin $E_{1}$ : role of brain monoamines. Psychopharmacology 1978; 56: 235-237.

33. Gerhard Vogel $\mathrm{H}$ and Wolf gang $\mathrm{H}$ : Drug discovery and evaluation pharmacological assays. Springer-Verlag Berlin Heidelberg, New York. Fourth Edition 2002.

34. Alice $\mathrm{AL}$ and Alvin JB: Glycine potentiates strychnine-induced convulsions: role of NMDA receptors. J Neurosci 1988; 8 (10): 3823-3826.

35. Curtis DR, Game CJA and Lodge D: Benzodiazepines and central glycine receptors. Br.J. Pharmac 1976; 56: 307-311.

36. Adeyemi OO, Akindele AJ, Yemitan $\mathrm{OK}$ and Fagbo FI: Anticonvulsant, anxiolytic and sedative activities of the aqueous root extract of Securidaca longependunculata fresen. J Ehanopharmacol 2010; 130: 191-195.

37. Nandakumar J and Manoj GT: Evaluation of cyclic nucleotide phosphodiesterase III inhibitors in animal models of epilepsy. Biomedical research 2008; 19: 13-17.

38. Veronica BB, Joao BT, Rocha and Vanderlei Folmer: Diphenyl diselenide and diphenyl ditelluride increase the latency for 4aminopyridine-induced chemical seizure and prevent death in mice. Acta Biochemica Polonica 2009; 56: 125-134.

39. Watts $A E$, Jefferys JGR, Effects of carbamazeipine and baclofen on 4-aminopyridine-induced epileptic activity in rat hippocampal slices. Br. J. Pharmacol 1993; 10: 819-823.

40. Om Prakash Mishra, Deepak S, Ram S U and Divya A: Cerebrospinal fluid zinc, magnesium, copper and gammaaminobutyric acid levels in febrile seizures. J Child Neurol 2007; 5: 39-44.

41. Chintawar RS, Somani RS, Veena S K and Kasture SB: Nootropic activity of Albizzia lebbeck in mice J Ethanopharmacol 2002; 81: 299-305.

42. Maharudra SR and Sanjay RC: Evaluation of CNS depressant activity of momordica dioica (Roxb) wild fruit pulp. Int J Pharm Pharm Sci 2010; 2: 124-126.

43. Ragwaski MA, Porter RJ: Antiepileptic drugs and pharmacological mechanisms and clinical efficacy with consideration of promising development stage compounds. Pharmacological Review 1995; 42: 223-286.

44. Macdonald RL, Kelly KM: Antiepileptic drug mechanisms of action. Epilepsia 1995; 36: S2-S12.

45. Subramanium S, Rho JM, Penix L, Donevan SD, Fielding RP and Rogawski MA. Felbamate block of the N-methyl-D-aspartate receptor. J Pharmacol Exp Ther 1995; 273: 878-886.

46. Macabe RT, Wasterlaine CG, Kucharczyk N, Sofia RD and Vogel JR: Evidense for anticonvulsant and neuroprotectant action of felbamate mediated by strychnine insensitive glycine receptors. J Pharmacol Exp Ther 1993; 264: 12481252.

47. Wang WP, Iyo AH, Miguel-Hidaglo J, Regunathan S and Zhu MY: Agmatine protects against cell damage induced by NMDA and 
glutamate in cultured hippocampal neurons. Brain research 2006; 1084 (1): 210-216.

48. Adeyemi OO, Akindle AJ, Yemitan OK, Aigbe FR and Fagbo FI, Anticonvulsant anxiolytic and sedative activities of the aqueous root extract of Secridaca longependunculata Fresen. Ethnopharmacol 2010; 130 (2): 191-195.

49. Yasuyoshi I, Masashi N and Masato Y: Effect of isoniazid on the pharmacodynamics of cefazolin-induced seizures in rats. Drug Metab. Pharmacokinets 2005; 20 (2): 117-120.

50. Thesleff S: Amino pyridines and synaptic transmission. Neurosci 1980; 5 (8): 1413-1419.

51. Rogawski MA and Barker JL, Effects of 4-aminopyridine on calcium action potentials and calcium current under voltage clamp in spinal neurons. Brain Res 1983; 280 (1): 180-185.
52. Morales-Villagrán A, Ureña-Guerrero M, Tapia R, Protection by NMDA receptor antagonists against seizures induced by intracerebral administration of 4-aminopyridine. Eur J Pharmacol 1996; 305(1-3): 87-93.

53. Tapia R, Medina-Ceja L and Pena F: On the relationship between extracellular glutamate, hyperexcitation and neurodegeneration in vivo. Neurochem Int 1999; 34 (1): 23-31.

54. Fragoso-Veloz J and Tapia R: NMDA receptor antagonists protect against seizures and wet-dog shakes induced by 4-aminopyridine. Eur J Pharmacol 1992; 221 (2-3): 275-280.

55. Ramnathan M, Shivakumar S, Anandvijaykumar PR, Saravanababu $C$ and Rathinavel PP: Neuroprotective evaluation of standardised extract of centella asciatica in monosodium glutamate treated rats. Indian J. Expt. Biol 2007; 45 (5): 425-431 